\title{
Muslimer i mandtal - tal, fordomme og politik i Europa ${ }^{1}$ \\ Brian Arly Jacobsen
}

\section{Resumé}

En diskussion af forskellige estimationer over de muslimske populationer i Europa viser, at den offentlige debat om tal reflekterer akademias problemer med at kvantificere de muslimske populationer. Estimationer over distributioner af muslimer i Europa varierer i vid udstrækning på grund af mangelen på metodologisk og begrebsmæssig konsensus. I artiklen diskuteres forskellige religionsdemografiske metoder og prognoser. En mere præcis estimation af muslimer baseret på troværdig statistik foreslås. Endelig foreslås en metode til en mere realistisk udregning af antallet af muslimer i lande hvor direkte data ikke er tilgængelig.

Måske får islamforskningens 'grand old man', Bernard Lewis, så virkelig ret i sin forudsigelse om, at Europa mod slutningen af det 21. århundrede vil være totalt islamiseret? (Kirsten Sarauw, præst og psykoterapeut i Politiken 6. maj 2006)

Tilstedeværelsen af muslimer i det vestlige Europa i dag er primært et resultat af den massive indvandring af arbejdskraft og flygtninge fra Mellemøsten og tidligere kolonier i Afrika og Asien. Denne beskrivelse, uanset hvor simpel den måtte være, er tydelig på vidt forskellig måde i Europa. Også selvom der har været muslimer i Vesteuropa i flere hundrede år. Det være sig handelsfolk, diplomater og studerende, men også som et resultat af historiske omstændigheder i forbindelse med det osmanniske rige og dets indflydelse på Balkan samt små lommer af tatarer i Østeuropa, Sverige og Finland. Tatarernes indvandring til Finland og Sverige betød i øvrigt, at de første muslimske forsamlinger i Nordeuropa blev grundlagt i henholdsvis 1925 i Helsingfors og 1949 i Stokholm (Stenberg 2002:122). Nogle vil af forskellige grunde gerne og helst tale om den nye muslimske tilstedeværelse i Europa. Denne fortælling er ikke korrekt set fra et historisk perspektiv og i øvrigt også noget eurocentrisk, specielt hvis man tager de postkoloniale samfund i Europa i betragtning, såsom Storbritannien, Frankrig og Holland. ${ }^{2}$ Indtil det koloniale projekts afslutning, var millioner af muslimer statsborgere i de britiske, franske eller hollandske stater, om end de var bosat udenfor Europa. Den kendsgerning, at mange af dem immigrerede til de europæiske centre er del af den samme historiske proces. Set fra migrantens perspektiv, kan situationen koges ned til følgende sætning: vi er her, fordi I var der.

Alligevel havde tilstedeværelsen af muslimske borgere i koloniale områder en meget lille indflydelse på den lokale situation i Europa. Uanset hvilken forskningsmæssig position man har til disse kendsgerninger - om man tilslutter sig betydningen af den historiske 
kontinuitet eller ej - er det klart, at vi nu har med en ny situation at gøre på mange forskellige måder: Muslimer i Europa udviser en stor variation i etnisk, sproglig, religiøs og kulturelle karakteristika og har mange forskellige forbindelser med andre store muslimske regioner i verden. Som migranter finder de ofte sig selv placeret i ukendte og til tider fjendtlige omgivelser, hvor muligheden for udøvelse af islam ikke er nogen selvfølge. Det indebærer og fortsætter med at indebære diskussioner og lejlighedsvis konflikter med repræsentanter fra modtagerlandets majoritetsbefolkning, mens muslimer selv er gået ombord i selvanalytiske diskussioner om deres religion og religiøse praksis og er dermed i gang med at udvikle nye former for islam tilpasset og påvirket af situationen i de nye omgivelser. $^{3}$

Spørgsmålet om antallet af muslimer i europæiske lande har også fået stigende opmærksomhed i de senere år. ${ }^{4}$ Der er tilsyneladende et stort behov hos politikere, myndigheder og offentligheden for at få af vide, hvor mange muslimer der egentlig findes i forskellige europæiske lande samt på et europæisk plan. Ikke sjældent forekommer urealistisk høje tal, som vi skal se senere i artiklen. Spørgsmålet er omstridt og højt placeret på den politiske dagsorden.

Denne artikel vil vise hvordan spørgsmålet om antallet af muslimer politiseres i en dansk kontekst, og hvordan forskellige forskeres metoder og opgørelser er med til at konstruere forestillinger om hvem der er muslimer og hvor mange de er. I forlængelse heraf præsenteres en mere realistisk optælling af antallet af muslimer i Europa, som kan danne grundlaget for religionsdemografiske analyser, der kan aflive mange af de forestillinger, som hersker i offentligheden om antallet af muslimer i nutidens og fremtidens Danmark og Europa. Endelig vil artiklen afslutningsvis kort præsentere en metode til at opgøre antallet af muslimer på, som kan benyttes i de europæiske lande, som ikke har adgang til direkte data om religiøst tilhørsforhold fra folketællinger eller lignende.

\section{Den europæiske anden}

Modstillingen 'Europas befolkning' overfor 'den muslimske befolkning' er ingenlunde ny - i den statistiske udgave er den i nogen henseender en afart af den velkendte modstilling occidenten-orienten, som kendes helt tilbage fra middelalderen. ${ }^{5}$ 
I mange fremstillinger beskrives de muslimske migrantgrupper ofte med krigsmetaforer, som 'invasion', 'horder' og 'krig'. ${ }^{6}$ Derfor er der en vis logik i at overvurdere antallet af muslimer. Tallet i sig selv bliver en del af den politiske arena, hvor kampe om migrantgruppers adgang, levevilkår og rettigheder diskuteres. De muslimske ledere ser også fordele $\mathrm{i}$ at overvurdere antallet af muslimer: jo flere muslimer jo stærkere en minoritet, som (berettiget eller uberettiget) dermed kan kræve statslige og offentlige privilegier for de muslimske minoriteter samt politisk indflydelse på egne vegne. Det er et politisk tal, som det kræver en forskningsmæssig indsats at afpolitisere, så den europæiske offentlighed, de muslimske grupperinger og den interesserede forsker igen kan diskutere muslimer og antal uden at blive beskyldt for at 'gå et politisk ærinde'.

\section{'Muslimernes antal vokser og vokser'}

Eksempler på forestillinger om antallet af muslimer i Danmark er legio. Jeg skal her fremdrage to eksempler. Det ene eksempel er europaparlamentsmedlem Mogens Camres (Dansk Folkeparti) estimering af muslimer i et indlæg i Berlingske Tidende 1. juni 2004 med titlen 'Muslimernes tal vokser og vokser', hvor han siger:

Dansk Folkeparti ser, ligesom de fleste andre borgere i EU, en alvorlig trussel i den folkevandring, der er i gang fra den muslimske verden til EU. Den vil blive voldsomt forøget, hvis Tyrkiet bliver medlem af EU.

I Danmark er der allerede mange flere muslimer end det indvandrertal, Danmarks Statistik opgør. I virkeligheden opgør Danmarks Statistik slet ikke antallet af muslimer. Danmarks Statistik opgør 'indvandrere og efterkommere fra tredjeverdenslande' (hvoraf de allerfleste er muslimer), men heri indgår ikke muslimer, der er født i Danmark af muslimske forældre, hvoraf blot den ene har dansk statsborgerskab, ligesom andre danske muslimer slet ikke medregnes. Antallet af muslimer i Danmark er derfor ikke 5,8 pct., men snarere 10 pct., og det er i rivende udvikling.

Ifølge Camre er der altså ca. 540.000 muslimer i Danmark. Samtidig formår han på ganske subtil vis, at få antallet af muslimer i officielle eller forskningsmæssige opgørelser til at være 5,8 pct. hvilket svarer til 313.200 muslimer. Altså er der to tal i den tekst, som tilsammen danner en forestilling om antallet af muslimer, som noget større end de fleste muslimforskere sikkert ville vurdere det. Lignende forestillinger er genstand for en prognose over antallet af muslimer i Danmark i en klumme af sognepræst og psykoterapeut Kirsten Sarauw i Politiken:

Ifølge en demografisk fremskrivning, foretaget på Københavns Universitet, vil Danmark om godt 50 år rumme et flertal af mennesker med udenlandsk oprindelse. Heraf 
langt de fleste med muslimsk baggrund. Tilsvarende resultater er demografer nået til for Norges vedkommende. Resten af Europa vil formentlig følge trop. Måske får islamforskningens 'grand old man', Bernard Lewis, så virkelig ret i sin forudsigelse om, at Europa mod slutningen af det 21. århundrede vil være totalt islamiseret? ('Det religiøse rum: Folkekirken skal undervise', Politiken 6. maj 2006)

Sarauw (re)producerer en forestilling om at muslimerne om godt 50 år vil være, om ikke en majoritet, så næsten en majoritet og Europa - herunder Danmark - vil være islamiseret, hvad det end betyder. Det vækker bekymring hos Sarauw, som legitimerer sin forestilling videnskabeligt med henvisning dels til Københavns Universitet dels "islamforskningens 'grand old man', Bernard Lewis". Den første henvisning er en henvisning til en ikke-eksisterende undersøgelse - i øvrigt viser alle befolkningsprognoser, som generelt er en meget usikker geschæft, et ganske andet billede. Der findes ingen særskilt prognose for befolkningsudviklingen over muslimer i Danmark, men hvis man et kort øjeblik ignorerer det faktum at langtfra alle indvandrere og efterkommere fra ikke-vestlige lande er muslimer, så viser en prognose udarbejdet af Danmarks Statistik for Ministeriet for Flygtninge, Indvandrere og Integration fra 2005, at antallet af indvandrere og efterkommere fra ikke-vestlige lande vil stige fra at udgøre 5,9 pct. af befolkningen i 2005 til at udgøre 11,2 pct. i 2050. Det er omtrent dobbelt så mange indvandrere og efterkommere fra ikke-vestlige lande som i 2005 (Årbog om udlcendinge i Danmark 2005: 59). Den anden henvisning i Sarauws citat tegner et billede af Bernard Lewis som en autoritet for hele islamforskningen, hvilket ikke er tilfældet (Salvatore 1997: 141-4, 244; Said 2002: 370-94).

Klummen er en speciel genre, et sted mellem debatindlæg og analytiske kommentarer. Der er tilsyneladende en stor frihed for klummeskrivernes skriveri uden redaktionel indblanden - skulle man tro.

Men det er måske ikke så mærkeligt, for en stor del af den danske befolkning deler tilsyneladende Sarauws forestilling om fremtidens Danmark. Ifølge en meningsmåling foretaget af Rambøll Management for avisen Jyllands-Posten den 23. og 30. maj 2004 tror 24 pct. af danskerne, at muslimer i fremtiden vil udgøre et flertal af Danmarks befolkning. Blandt disse tror 59 pct., at det vil ske inden for de næste 30 år. Danmarks Statistiks prognoser tegner, som nævnt ovenfor et andet billede. Med de foreliggende opgørelser over antallet af muslimer sammenholdt med ikke-vestlige indvandreres fertilitetskvotient, må man konstatere, at en sådan situation er helt urealistisk. 
Samfundsforskeren Lise Togeby gør i samme artikel i Jyllands-Posten den 23. maj opmærksom på, at tallene afspejler befolkningens bekymringer og frygt, og udtaler i den sammenhæng at "debatten om flygtninge og indvandrere fylder meget i Danmark i dag. Og danskerne placerer deres stemme efter det. Det gjorde de ikke tidligere”. Spørgsmålet om antallet af muslimske indvandrere i Danmark har i dette perspektiv stor indflydelse på dansk politik. Når politikere italesætter muslimer i Danmark som en trussel, som en berigelse eller blot henviser til dem som en deskriptiv størrelse, så gør de det altså uden at kende et nogenlunde sikkert antal muslimer inden for landets grænser (Jacobsen 2007:143-165).

Der er altså behov for mere troværdige statistikker til at aflive myter om muslimernes antal i den offentlige debat. Disse statistikker kan, hvis de er detaljerede nok, danne baggrund for nødvendige demografiske analyser af den muslimske befolkningsgruppe (dette gælder naturligvis også demografiske analyser af andre migrantgrupper såsom baha'i, hinduer og buddhister). Her kommer religionsdemografien ind i billedet. Religionsdemografi er ikke et etableret fag ved nogen universiteter, men i takt med den stigende offentlige interesse for gruppers sammensætning og antal, er udviklingen af en egentlig religionsdemografi i sin begyndende fase (Warburg 2007a:5-13).

\section{Demografi - religionsdemografi}

Demografi er det statistiske studie af befolkningen. Det indeholder studiet af størrelse, struktur og fordeling af befolkninger over (geografisk) rum og/eller tid i relation til sociale karakteristika såsom fødsel, død, køn, alder, erhverv, uddannelse, nationalitet, migration og religion.

Den formelle demografi begrænser sit objekt til at måle befolkningsprocesser, mens det bredere socialdemografiske felt også analyserer sammenhænge mellem økonomi, social, kulturel og biologiske processer, som har indflydelse på befolkningsprocesserne (Matthiessen 2004: 7-11).

\section{Data og metoder}

Der er to metoder for dataindsamling: direkte og indirekte. 
Direkte data kommer fra officielle statistiske efterretninger som registrerer fødsel og død såvel som visse forandringer i den juridiske status, såsom ægteskab, skilsmisse og migration (registrering af opholdssted). Allerede her spiller religiøse institutioner og religiøse grupper en rolle; i mange lande, herunder til dels Danmark, er det religiøse institutioner som har (d)en juridisk samt en ikke uvæsentlig kulturel autoritet i forbindelse med fødsels-, døds,- ægteskabs- og skilsmisseregistrering. ${ }^{7}$ I forbindelse med migration er det ofte, men ikke altid, migrantens religiøse baggrund, som spiller en rolle i italesættelsen af migrantgrupper - ofte i rigide kategoriseringer af majoritetssamfundet. Dette gælder ikke mindst i forhold til forskellige muslimske grupperinger i Europa (European Monitoring Centre on Racism and Xenophobia 2006:108-110; Report on International Religious Freedom 2007). I lande med gode registreringssystemer, såsom i det meste af Europa, Nordamerika og Australien, er officiel statistik den bedste metode til at estimere antallet af fødsler, død og migration.

Folketællingen er den anden direkte indsamlingsmetode for demografisk data. En folketælling er normalt udført af nationale regeringer, som forsøger at optælle alle personer i et land. Imidlertid optræder folketællinger typisk hvert tiende år i modsætning til officielle statistikker som typisk indsamles kontinuerligt og opregnes på årlig basis. Folketællinger er derfor ikke de mest pålidelige data som kilde til oplysninger om fødsel, død m.m. i sammenligning med officielle statistikker. Folketællinger gør mere end at tælle mennesker. Typisk indsamler de data om familie/hushold såvel som individuelle karakteristika såsom alder, køn, ægteskabelig status, uddannelse (evt. alfabetiseringsgrad), erhverv, erhvervsmæssig status, og geografisk bosted. De kan også bruges til at indsamle data om migration (fødselssted), sprog, religion, nationalitet (eller etnicitet) og borgerskab. I lande med officielle statistikker, som i Danmark, er der mange af disse individuelle karakteristika, som det ikke er muligt at indsamle information om enten af politiske eller praktiske grunde.

Indirekte dataindsamlingsmetoder er nødvendige i lande, hvor der ikke eksisterer fyldestgørende data. Det er typisk i tredjeverdens lande, men det gælder også for nogle af de førnævnte individuelle karakteristika i rige vestlige lande. Man er derfor nødt til at udvikle nye dataindsamlingsmetoder til at estimere antal og sammensætning af en udvalgt gruppe. Det gælder eksempelvis spørgsmålet om, hvor mange muslimer der er i lande 
som Danmark, Sverige og Frankrig. For Danmarks vedkommende stoppede man oprindeligt med at registrere religiøst tilhørsforhold i folketællingerne af praktiske grunde. ${ }^{8}$ Siden hen blev officiel registrering af blandt andet religiøst tilhørsforhold en del af registertilsynsloven, hvorefter det blev et politisk princip ikke at registrere religiøst tilhørsforhold officielt. ${ }^{9}$ I Frankrig har det siden 1905 været et af principperne bag laïcite (adskillelse af kirke/religion og stat), at staten ikke måtte registrere religiøst tilhørsforhold (Burleigh 2005: 362-4, Report on International Religious Freedom 2004). For nogle lande har det altså været en bevidst politik at stoppe officiel indsamling af data om religiøst tilhørsforhold, mens det for andre mere har været af praktiske årsager eller tilfældigheder, der har afstedkommet afskaffelsen af indsamling af denne type data. I Danmark er den sidste offentliggjorte religionstælling i forbindelse med folketællingen fra 1921.

Religionsdemografi findes i krydsfeltet mellem discipliner som religionsvidenskab, geografi, statistik, demografi, sociologi og antropologi og skal ligesom demografi udvikle tilgange til en lang række befolkningsmæssige spørgsmål ved at kombinere mere tekniske kvantitative tilgange. Disse repræsenterer disciplinens kerne med mange andre metoder lånt fra andre samfundsvidenskabelige og humanistiske discipliner.

\section{Opgørelser over antallet af muslimer i Europa}

Før man kan gå i gang med de mere interessante demografiske analyser af en befolkningsgruppes sammensætning - eksempelvis muslimer i Europa - hvad angår parametre som køn, alder, uddannelse, bosted, etnicitet og så videre, forudsætter det et talmæssigt grundlag, som er troværdigt, og som er til at arbejde med. I denne artikel er det udelukkende opgaven, at diskutere det talmæssige grundlag for estimeringen af muslimer i Europa.

Mange forskere har forsøgt at udregne antallet af muslimer, som en samlet gruppe i Europa eller EU. ${ }^{10}$ Jeg vil i det følgende diskutere fire eksempler på udregninger og analyser af tal og prognoser, som typiske for forskningsområdet.

Den engelske demograf Mark Brown diskuterer spørgsmålet om metodologi og hvem der kan tilhøre de muslimske befolkningsgrupper i statistiske undersøgelser i artiklen "Quantifying the Muslim population in Europe: conceptual and data issues" (Brown 2000). Brown er fortaler for en mangfoldighed af metodologiske og empiriske tilgange og disku- 
terer forbilledligt fordele og ulemper ved forskellige data og indsamlingsmetoder, men Brown applicerer aldrig selv metoderne på udvalgt data. Artiklen er dermed kun en metodologisk diskussion, som kan virke som inspirationskilde eller ej.

Den amerikanske "Distinguished Professor of History and Religious Studies" Philip Jenkins diskuterer bl.a. spørgsmålet om antallet af muslimer og demografiske prognoser i artiklen "Demographics, Religion, and the Future of Europe" (Jenkins 2006). Artiklen er det klassiske eksempel på en religionsforsker der blander egne sympatier for religionernes positive indvirkning på samfundet per se, med en såkaldt objektiv videnskabelig analyse af den religiøse situation og udvikling i Europa (jf. især 536-37). Da dette ikke er en anmeldelse af hele artiklen, vil jeg i det følgende kun forholde mig til artiklens empiriske grundlag og analyserne af dette. Jenkins er, som mange før ham, ikke tydelig i hvilke data han benytter i opgørelser over kristne og muslimer i Europa. Han nævner et enkelt sted, at der ifølge World Christian Encyclopedia er 560 millioner kristne i Europa, men herudover er der ingen referencer til datagrundlaget. ${ }^{11}$ I artiklens tabel over den muslimske befolkningsgruppe i Europa er nævnt ni landes muslimske befolkningsgruppe - et tal på 14,5 millioner muslimer, mens han i artiklen slår fast, at antallet er muslimer fra 1970 til 2000 er vokset fra 18 til 32 millioner i Europa. Der er ingen reference til datagrundlag (ibid.: 532). Krydstjekker man sidstnævnte tal med oplysningerne i World Christian Encyclopedia aner man dog, at datagrundlaget er fra denne (Barret et al. 2001: 14). For at gøre forvirringen større så gælder det dog ikke tabellen, som har helt andre og større tal, end hvad World Christian Encyclopedia har for samme lande. Andre steder i artiklen omtaler Jenkins demografiske prognoser for udviklingen i antallet af muslimer for enkelte lande, som skal tegne et billede af en hurtigvoksende muslimsk befolkningsgruppe. For Frankrig gælder det eksempelvis, at muslimer fra at udgøre højest 7,8 pct. af befolkningen i 2007, vil de ifølge Jenkins givetvis udgøre 30 pct. i 2050 (Jenkins 2006: 533). Igen er der ingen referencer, og kender man til situationen i Frankrig vil man vide, at begge tal er helt urealistiske. Det er kun muslimske organisationer og politikere, som af forskellige årsager ønsker antallet af muslimer i Frankrig 'pustet' op på 5 millioner eller derover antallet er mere realistisk 3,65 - 5 millioner jf. den grundige diskussion af forskellige antalsopgørelser i Frankrig i Laurence og Vaisse (2006: 18-19). Disse tal svarer til mellem 5,7 pct. og 7,8 pct. af Frankrigs befolkning i 2007 tal. Hvis denne befolkningsgruppe i 
løbet af 43 år skulle fire- til femdobles vil det være intet mindre end en befolkningsudviklingsmæssig sensation. På samme måde ekstrapolerer Jenkins urealistiske tal fra andre lande, og når frem til, at muslimske befolkningsgrupper i Europa vil udgøre ca. 25 pct. af Europas befolkning i 2050. Således kan vi konkludere, at selv "Distinguished Professors" $\mathrm{i}$ anerkendte politologiske tidsskrifter uden problemer kan benytte sig af et problematisk datagrundlag, af fantasifulde demografiske prognoser og i konsekvens af dette tegne apokalyptiske billeder af Europas fremtid (Jenkins 2006: 536).

Demograferne Westoff og Frejka analyserer i artiklen "Religiousness and Fertility among European Muslims" fertiliteten blandt europæiske muslimer og sammenligner den med gennemsnitseuropæernes. I artiklen opgører de antallet af muslimer i udvalgte europæiske lande mellem 2005 og 2006. Her estimeres det blandt andet, at der er 270.000 muslimer i Danmark, hvilket er ca. 35 pct. højere estimat end hvad danske forskere når frem til for samme år (Kühle 2006: 42; Jacobsen 2007: 158-59). De redegør ikke nærmere for hvordan de når frem til deres estimat, men henviser blot til nationale statistiske efterretninger eller andenhåndskilder som eksempelvis BBC (2005), som ikke er nærmere undersøgt. Jeg antager, at de i mangel af bedre har adderet etniske kategorier i de enkelte landes nationale statistiske efterretninger. En etnificering af religion, som naturligvis er helt uholdbar, da ikke alle pakistanere eller tyrkere kan medregnes som muslimer i et sådan estimat, ligesom ikke alle danskere er kristne (Baumann 1996:72-108; 188-190). Det samlede antal muslimer i Europa eksklusiv Rusland og Tyrkiet er ifølge Westoff og Frejka 35-45.000.000. Et højt estimat, som desværre ikke gennemgås nærmere, da kun 23 landes antal vises $\mathrm{i}$ deres tabel, hvorfor det ikke er muligt at vurdere validiteten $\mathrm{i}$ deres udregning (Westoff og Frejka 2007: 786). Om hvorvidt antallet er 35 eller 45 millioner har stor betydning $\mathrm{i}$ en befolkningsprognose, derfor er denne del af artiklen ikke videre troværdig.

Til gengæld er deres diskussion og analyse af europæiske muslimske kvinders fertilitetskvotient både grundig og troværdig. På baggrund af data, der dækker muslimske kvinder i Europa i alderen 18-44, fra de europæiske værdiundersøgelser fra 1990, 1995-97 og 1999-2000, når de frem til, at det gennemsnitlige antal af børn for muslimske kvinder er 1,6, mens det for ikke-muslimske kvinder er 1,3. Generelt viser forskellige undersøgelser, også i Danmark (Arbog om udlcendinge i Danmark 2004:62-64; Arbog om udlcendinge i 
Danmark 2005:58), at indvandrerkvinders fertilitet hastigt nærmer sig den fertilitetssituation, som er fremherskende i det land, som indvandreren bosætter sig i (Westoff og Frejka 2007: 796-98). Fertilitetskvotienten viser sig altså at være noget lavere end de tal, som gælder for danske befolkningsprognoser (Årbog om udlcendinge i Danmark 2005: 59; Matthiessen 2004: 87-88). Denne del af artiklen bidrager med nye vigtige oplysninger på baggrund af data fra de europæiske værdiundersøgelser, som viser, at forskere som Jenkins (2006) og Bernhard Lewis ikke har ret i deres demografiske prognoser over de europæiske muslimske befolkningsgrupper.

Endelig diskuterer den danske islamforsker Jørgen Nielsen spørgsmålet om statistik i Muslims in Western Europe (1995). I kapitlet "A note on statistics" diskuterer Nielsen problemerne med indsamling af data, dataenes inkomparativitet landene imellem og definitionsproblemer hvad angår forskellige grupper af muslimer, selvdefinitioner etc. Han beskriver hvordan indsamlingen af data om muslimers antal i hans undersøgelse er baseret på etnisk baggrund i forskellige landes statistik (Nielsen 1995: 170-71). Det er en ofte anvendt metode, som tidligere nævnt, men metoden har flere problemer: Man kan som forsker ikke forlange, at offentligheden skal kunne differentiere mellem forskellige måder at være muslim på eller ikke at betragte alle indvandrere fra et givent land som muslimer, hvis forskerne ikke selv foretager en sådan differentiering i eksempelvis undersøgelser af antallet af muslimer i Europa. Den etnificerende kortslutning mellem religion og etnicitet er desværre udbredt blandt mange forskere, hvorfor det ikke kan overraske, at samme kortslutning er almindelig i den offentlige debat. Der mangler derfor mere præcise opgørelser og en forskningsmæssig indsats blandt europæiske forskere, der beskæftiger sig med muslimer, så man kan nå frem til et mere præcist antal af muslimer for de lande, hvor der ikke eksisterer folketællinger eller pålidelige religionsstatistikker.

Tabel 1. er en oversigt over nogle af de mange estimeringer af muslimer i Europa, som er fremkommet $\mathrm{i}$ de seneste år. Udregningerne varierer for antal af muslimer i EU fra 6.837 .100 i $1995,,^{12}$ (Peach og Glebe) til 16.731 .390 i $2007,,^{13}$ (Report on International Religious Freedom 2007). Denne forskel i estimering af muslimer skyldes en udvidelse af medlemslande samt indvandring til EU i de pågældende år, men kan ikke forklare hele differencen. $^{14}$ 
Tabel 1. Opgørelser over antallet af muslimer i Europa og EU.

\begin{tabular}{|c|c|c|c|c|}
\hline & Antal muslimer Europa & Antal muslimer EL & & Kilde \\
\hline 1994 & 13.194 .000 & & & $\begin{array}{l}\text { Britannica Book of the Year } \\
1994^{1}\end{array}$ \\
\hline 1995 & 31.975 .000 & & & $\begin{array}{l}\text { Britannica Book of the Year } \\
1995^{1}\end{array}$ \\
\hline 1995 & 23.589 .600 & 6.837 .100 & & Peach og Glebe ${ }^{2}$ \\
\hline 1997 & 30.426 .700 & 6.837 .100 & & Vertovec og Peach ${ }^{3}$ \\
\hline 2002 & $13.150 .695-14.138 .695$ & & & Maréchal (Coord.) ${ }^{4}$ \\
\hline 2003 & $12.440 .000-13.458 .000$ & $11-12.000 .000$ & & Maréchal et al ${ }^{5}$ \\
\hline 2003 & & 15.157 .000 & & Financial Times ${ }^{6}$ \\
\hline 2005 & $88.524 .800-89.524 .800$ & & & $\mathrm{BBC}$ \\
\hline 2006 & & 12.975 .390 & & $\begin{array}{l}\text { European Monitoring Centre } \\
\text { on Racism and Xenophobia }\end{array}$ \\
\hline 2006 & 33.260 .800 & & & $\begin{array}{l}\text { Britannica Book of the Year } \\
2006^{1}\end{array}$ \\
\hline 2007 & 53.700 .000 & 15.900 .000 & & Reformatorisch Dagblad $^{7}$ \\
\hline 2007 & & $\begin{array}{l}12.415 .141 \\
14.704 .426\end{array}$ & - & Dasetto et. al (2007: 81-173) \\
\hline $2007(1)$ & $\begin{array}{l}116.594 .014 \\
128.185 .014^{8}\end{array}$ & $\begin{array}{l}15.670 .590 \\
16.731 .390\end{array}$ & - & $\begin{array}{l}\text { Report on International Reli- } \\
\text { gious Freedom (2007) }\end{array}$ \\
\hline $2007(2)$ & $\begin{array}{l}30.720 .014 \\
33.311 .014^{8}\end{array}$ & $\begin{array}{l}15.670 .590 \\
16.731 .390\end{array}$ & - & $\begin{array}{l}\text { Report on International Reli- } \\
\text { gious Freedom (2007) }\end{array}$ \\
\hline
\end{tabular}

\footnotetext{
${ }^{1}$ Denne udregning baserer sig på World Christian Encyclopedia (Barrett et al. 1982). Der er ingen forklaring på det store spring fra 1994 til 1995 udover en ændret prognose fra 1994 til 1995. Efter 2001 benytter Britannica Book of the Year værket World Christian Encyclopedia, 2nd ed. (Barrett et al. 2001). Rusland og tidligere sovjetrepublikker er med i denne udregning, mens Tyrkiet ikke nævnes.

${ }^{2}$ Denne udregning trækker på forskellige kilder fra forskellige år og har forskellige grader af præcision. Antal muslimer Europa inkluderer det tidligere Sovjetunionen med 11.500.000, men er eksklusiv den europæiske del af Tyrkiet. Den dækker kun 22 lande i Europa i alt.

${ }^{3}$ Denne udregning trækker på forskellige kilder fra forskellige år og har forskellige grader af præcision. Antal muslimer Europa inkluderer tidligere Sovjetunionen med 11.500.000, men er eksklusiv den europæiske del af Tyrkiet.

${ }^{4}$ Denne udregning trækker på forskellige kilder fra forskellige år og har forskellige grad af præcision. Der mangler endvidere vigtige lande i udregningen såsom tidligere Jugoslavien, Albanien samt de europæiske dele af det tidligere Sovjetunionen. Den indeholder kun estimat for 19 lande.

${ }^{5}$ Estimat ultimo 1990'erne. Antal muslimer Europa gælder kun: Bulgarien, Ungarn, Norge, Polen, Rumænien og Schweiz. Disse lande er altså lagt til EU landenes antal. Der er en fejl i deres opgørelse, da Norge med estimerede 23.000 muslimer (!) optræder under både EU og Europa (Maréchal et al.: xxv).

${ }^{6}$ Før udvidelsen mod Østeuropa samt uden Finland, Irland og Portugal.

${ }^{7}$ Kilde: Zentral-Institut Islam-Archiv-Deutschland (heraf 25.000.000 i Rusland og 5.900.000 i den europæiske del af Tyrkiet).

${ }^{8}$ Addering af landeoplysninger i rapporten fra 2007. Udregning (1) er inkl. hele Rusland og Tyrkiet, udregning (2) er uden Rusland og Tyrkiet.
} 
En del af differencen skyldes også forskernes forskellige metoder og beregningsgrundlag. For eksempel ser forskellige estimeringer for hele Europa således ud; 13.194.000, svarende til 2,56 pct. af Europas samlede befolkning i 1994 til 33.311.014, svarende til 5,6 pct. af Europas befolkning i 2007 eller 128.185.014, svarende til 15,82 pct. af Europas samlede befolkning i 2007 alt efter om Tyrkiet og Rusland er udeladt eller ej. Igen kan indvandring forklare en del af stigningen, men ikke hele stigningen som udgør mere end en fordobling af muslimer i Europa, hvorfor metode og det empiriske beregningsgrundlag igen spiller en rolle. Den relativt store difference kalder på konsensus hvad angår datagrundlag og metode.

\section{Forskellige datatyper i Europa}

I Europa optræder spørgsmål om religiøst tilhørsforhold, nationalitet, statsborgerskab og fødselssted i følgende EU og EFTA lande jf. Tabel 2. ${ }^{15}$

Især i folketællinger fra østeuropæiske lande som Bulgarien, Estland, Georgien, Letland, Litauen, Makedonien, Moldavien, Montenegro, Serbien, Slovakiet, Slovenien, Tjekkiet, og Ungarn spørges der til religiøst tilhørsforhold, men også i vesteuropæiske lande, såsom eksempelvis Irland og Storbritannien, stilles der spørgsmål om religiøst tilhørsforhold. Det er altså få europæiske lande, der har detaljeret viden om religiøst tilhørsforhold og dermed har viden om religiøse gruppers størrelse og sammensætning. Derfor er religionsdemografien blevet interessant som en ny forskningsdisciplin, der kan være med til at udvikle metoder til indsamling af data samt viden om religiøse gruppers sociale sammensætning og størrelse.

Enhver analyse af religionsdemografisk art lægger ud med at undersøge og tage stilling til forskellige afgrænsningsproblematikker, da det er vigtigt at få en veldefineret og relevant befolkningsgruppe at arbejde med. Hvem er f.eks. muslimer i Danmark? Der vil være meget stor forskel på at definere alle de personer i Danmark som er muslimer, som selv regner sig for muslimer og på at stille krav om, at disse personer også skal genkendes som muslimer af andre muslimer (Warburg 2007a:6). Betyder det endvidere, at man skal være medlem af en muslimsk menighed for at blive regnet med? Giver det mening religionsvidenskabeligt set, at stille krav om, at man skal være aktiv i menigheden, eller er man også muslim, når man engang har aflagt shahada, selv om man måske ikke har 
vist sig i menigheden i flere år? Skal man tælles med som muslim, hvis man samtidig er medlem af andre religiøse grupper, f.eks. folkekirken? Det er alle sammen vigtige og relevante spørgsmål, som det nødvendigt at tage stilling til, når man skal afgrænse kategorien 'muslim'. 16

Tabel 2. Indsamling af data på udvalgte individuelle identitetskategorier i officielle statistikker i udvalgte europceiske lande (folketcellinger, surveys og registre)

\begin{tabular}{|c|c|c|c|c|}
\hline & Religion & Etnisk gruppe & Fødselsoprindelse & Borgerskab \\
\hline Belgien & & & + & + \\
\hline Bulgarien & + & + & + & + \\
\hline Danmark & & & + & + \\
\hline Finland & + & & + & + \\
\hline Frankrig & & & + & + \\
\hline Grækenland & & & + & + \\
\hline Holland & & & + & + \\
\hline Irland & + & + & + & + \\
\hline Italien & & & + & + \\
\hline Letland & + & + & + & + \\
\hline Luxemburg & & & + & + \\
\hline Montenegro & + & + & + & + \\
\hline Norge & & & + & + \\
\hline Portugal & + & + & + & + \\
\hline Schweiz & + & & + & + \\
\hline Spanien & & & + & + \\
\hline Storbritannien & + & + & + & + \\
\hline Sverige & & & + & + \\
\hline Tyskland & + & & + & + \\
\hline Østrig & + & + & + & + \\
\hline
\end{tabular}

Inspireret af Coleman and Salt (1996:1-33). ${ }^{17}$

Der er flere problemer med de nuværende måder at opgøre antallet af muslimer på og jeg vil her pege på to. For det første findes der ingen autoritative opgørelser over distributionen af muslimer i Europa, eller opgørelsesmetoder som garanterer troværdige statistikker 
over antallet af muslimer - eller andre religiøse minoriteter for den sags skyld. Som tidligere beskrevet benytter mange forskere i mangel af relevante kilder ofte statistikker om indvandrernes statstilhørsforhold som indikation på religiøst tilhørsforhold. På den måde etnificerer man religion og gør det nærmest til et ufravigeligt biologisklignende karaktertræk ved den enkeltes identitet. En essentialisering, der også har politiske konsekvenser, især i relation til politisk definerede trusselsbilleder i de enkelte lande. Det er naturligvis en uholdbar situation. For det andet er grænserne for, hvad der hører med og ikke hører med til det muslimske fællesskab - hvis en sådan sociologisk kategori overhovedet eksisterer - uklar og lejlighedsvis genstand for en hed debat blandt muslimer og andre interessenter. Muslimer er ikke enige, hvad angår den præcise afgrænsning af, hvad der hører med under kategorien islam og, som konsekvens, er nogle af de troendes medlemskab af umma anfægtet. Det gælder f.eks. ahmadiyyaer, men især de individer, som uanset af hvilken grund, eksplicit har givet afkald på at være muslim og vælger en anden overbevisning eller som gradvist afsvækker og forlader deres tro. Om hvorvidt de sidstnævnte stadig skal betragtes som muslimer eller ej er et diskutabelt spørgsmål, selvom mange muslimer nok stadig ville tælle de ikke-troende og/eller sekulariserede individer med som en del af umma. Pointen er, at muslimer udviser en forskellighed i tilhørsforholdet til islam, varierende fra 'negative' individer som beskriver sig selv som ikke-troende, tavse agnostikere eller indifferente over kulturmuslimer til 'positive' individer der på forskellig vis bekender sig til og praktiserer islam aktivt.

Disse typer af tilhørsforhold forandrer sig over tid, blandt andet som resultat af ydre socialt pres. Det betyder, at individer som på et tidspunkt ikke forstår sig selv som muslimer, på et andet tidspunkt kan forvandles til hengivne muslimer og omvendt. Således peger Catinét Integrationsstatus' undersøgelser på en svagt stigende religiøsitet blandt unge muslimer (Jacobsen 2007: 150). Ikke-muslimer, som ikke er bevidste om de muslimske fællesskabers indviklede formationer og hvordan grænsen mellem at tilhøre og ikke at tilhøre er konstrueret, overvurderer ofte antallet af muslimer i Europa. Dette gør billedet af muslimske fællesskaber i Europa endnu mere mudret og upræcist.

Men uanset præcisionen i opgørelser over antallet af muslimer, er det en ubestridelig kendsgerning, at muslimers tilstedeværelse i Europa har fået langt mere offentlig og politisk betydning i de sidste par årtier (Jacobsen 2006). 
Tabel 3 er en opgørelse over antallet af muslimer i Europa. Hvert land er gennemgået med udgangspunkt i den amerikanske regerings Report on International Religious Freedom (2007), hvor kilder og referencer er tjekket. Hvis ikke der er fundet bedre referencer, eksempelvis et lands officielle statistik fra en folketælling (oftest via en hjemmeside) eller andet er Report on International Religious Freedom's (2007) estimering anvendt i opgørelsen. Den kan eksempelvis dække over lokale religiøse lederes vurdering eller regeringsoplysninger, som det ikke har været muligt at tjekke. Folketællingernes procentuelle estimering af antallet af muslimer er anvendt til at beregne antallet af muslimer ud fra befolkningsoplysninger fra 2007. Eksempelvis var der ifølge Montenegros folketælling i 200318 pct. muslimer, hvilket i 2003 svarede til 111.626 ud af i alt 620.145 indbyggere (Census of Population, Households and Dwellings 2003). I 2007 er indbyggertallet estimeret til 684.736 hvoraf 18 pct. muslimer således udgør 123.252 (CIA. The World Factbook 2007). Kilden til befolkningstal for 2007 er CIA. The World Factbook (2007).

Rusland og Tyrkiet er de store ubekendte faktorer i undersøgelsen. Store dele af begge lande hører til den asiatiske geografiske sfære og antallet af muslimer i de respektive landes europæiske dele er ubekendte. Man kan dog som udgangspunkt foretage en grov estimering af antallet af muslimer i den asiatiske sfære, baseret på antallet af muslimer i den europæiske sfære. Eksempelvis bor ca. 10 \% af Tyrkiets befolkning i den europæiske del, hvorfor man kan anvende dette tal som udgangspunkt for en grov estimering. For Rusland gælder det, at store dele af den muslimske befolkning bor i den asiatiske del i Kaukasusområdet, eksempelvis i Tjetjenien, mens et ukendt antal bor i den europæiske del af Rusland. De to lande er behandlet som to hele enheder i undersøgelsen. Det vil sige, at der i Europa med denne beregningsmetode er mellem 31.711.948 og 35.578.198 muslimer, hvilket svarer til 5,2-5,8 pct. af Europas befolkning. Inklusiv de ubekendte størrelser i Rusland og Tyrkiet er tallet noget større. Antallet varierer mellem 117.723.724 og 126.822.198 muslimer, hvilket svarer til 14,3-15,4 pct. af Europas befolkning. Hvilket tal der er mest relevant (med eller uden Rusland og Tyrkiet) vil ofte bero på en politisk vurdering, men det synes mest rimeligt, at benytte beregningen uden Rusland og Tyrkiet, da langt den største del af muslimerne bor i de to landes respektive asiatiske geografiske sfærer. Denne sfære er dog ligeså vilkårlig, som alle andre politisk vedtagne grænser. Optages Tyrkiet i EU, vil det være mest rimeligt, at inkludere landets muslimske befolk- 
ningsgruppe i opgørelser over muslimer i Europa. Således ville der i dag være ca. 12,6 pct. muslimer i Europa, hvis Tyrkiet blev inkluderet i beregningsgrundlaget.

Tabel 3. Estimering af antallet af muslimer i Europa

\begin{tabular}{|c|c|c|c|c|}
\hline Land & $\begin{array}{l}\text { Befolkning } \\
2007\end{array}$ & $\begin{array}{l}\text { Muslimer } \\
\text { (1. vurdering) }\end{array}$ & $\begin{array}{l}\text { Muslimer } \\
\text { (2. vurdering) }\end{array}$ & Kilder \\
\hline Albanien & 3.600 .523 & 2.340 .340 & 2.520 .366 & RIRF $2007^{1}$ \\
\hline Belgien & 10.392 .226 & 400.000 & 400.000 & RIRF 2007 \\
\hline Bosnien-Hercegovina & 4.552 .198 & 1.560 .000 & 1.820 .879 & UN $2002^{2}$ \\
\hline Bulgarien & 7.322 .858 & 951.972 & 951.972 & Folketælling $2001^{3}$ \\
\hline Danmark & 5.427 .459 & 207.186 & 207.186 & Jacobsen (2007) \\
\hline Frankrig & 63.713 .926 & 3.650 .000 & 5.000 .000 & Laurence et al. (2006) \\
\hline Grækenland & 10.706 .290 & 98.000 & 140.000 & RIRF 2007 \\
\hline Holland & 16.570 .613 & 911.384 & 994.237 & RIRF 2007 \\
\hline Hviderusland & 9.724 .723 & 194.494 & 291.742 & OPRRNA $(2007)^{4}$ \\
\hline Italien & 58.147 .733 & 800.000 & 1.000 .000 & EU $2007^{5}$ \\
\hline Kasakhstan & 15.284 .929 & 6.504 .595 & 7.159 .624 & Folketælling 1999 \\
\hline Kroatien & 4.493 .312 & 44.933 & 58.431 & RIRF 2007; CIA $^{6}$ \\
\hline Makedonien & 2.055 .915 & 657.893 & 684.620 & Folketælling 2002 \\
\hline Montenegro & 684.736 & 123.252 & 123.252 & Folketælling 2003 \\
\hline Rusland & 141.377 .752 & 14.137 .775 & 23.000 .000 & RIRF 2007; CIA \\
\hline Schweiz & 7.554 .661 & 324.850 & 324.850 & Folketælling 2000 \\
\hline Serbien & 10.150 .265 & 1.932 .800 & 2.075 .000 & Folketælling $2000^{7}$ \\
\hline Spanien & 45.116 .894 & 1.080 .000 & 1.080 .000 & RIRF 2007 \\
\hline Storbritannien & 60.776 .238 & 1.701 .735 & 1.701 .735 & Folketælling 2001 \\
\hline Sverige & 9.031 .088 & 400.000 & 450.000 & RIRF 2007 \\
\hline Tyrkiet (også i Asien) & 72.600 .000 & 68.244 .000 & 71.874 .000 & Folketælling $2000^{8}$ \\
\hline Tyskland & 82.400 .996 & 3.300 .000 & 3.500 .000 & REMID $2007^{9}$ \\
\hline Ukraine & 46.299 .862 & 500.000 & 500.000 & RIRF 2007 \\
\hline Østrig & 8.199 .783 & 344.391 & 344.391 & Folketælling 2001 \\
\hline $\begin{array}{l}\text { Andre (22 lande med } \\
\text { under } 100.000 \text { muslimer })\end{array}$ & 126.800 .696 & 350.372 & 383.682 & \\
\hline I alt i Europa & 823.026 .337 & 117.723 .724 & 126.822 .198 & \\
\hline Muslimer i pct. & & 14,3 & 15,4 & \\
\hline Uden Rusland og & 141.377 .752 & 14.137 .775 & 23.000 .000 & \\
\hline Tyrkiet & 72.600 .000 & 68.244 .000 & 71.874 .000 & \\
\hline & 609.048 .585 & 31.711 .948 & 35.578 .198 & \\
\hline $\begin{array}{l}\text { Muslimer i pct. uden } \\
\text { Rusland og Tyrkiet }\end{array}$ & & 5,2 & 5,8 & \\
\hline \multicolumn{5}{|c|}{$\begin{array}{l}\text { TIRF 2007: Report on International Religious Freedom (2007). } \\
{ }^{2} \text { U.N. Development Program's Human Development Report 2002. } \\
3 \text { Statistik fra The Council of Ministers Religious Confessions Directorate, Bulgaria, på baggrund af } \\
\text { folketællingen } 2001 \text {. } \\
{ }^{4} \text { Tal fra The Office of the Plenipotentiary Representative for Religious and Nationality Affairs (OPRRNA) } \\
\text { Januar } 2007 \text { (2. vurdering). The Committee of Religious and Nationality Affairs (CRNA) skriver, at der }\end{array}$} \\
\hline
\end{tabular}

(C) Forfatteren og Tidsskrift for Islamforskning, ISSN 1901-9580, publiceret 18-02-2008 
1.1.2006 var 4 pct. østlige religioner herunder islam, baha'i, ISKCON etc. Her estimeres med 3 pct. muslimer (1. vurdering).

${ }^{5}$ European Parliament's committee on Culture and Education 2007.

${ }^{6}$ CIA: CIA. The World Factbook (2007).

${ }_{8}^{7}$ Folketælling 2002: 5 pct. muslimer i Serbien, 80 pct. i Kosovo ifølge RIFR.

8 Folketælling 2000 og Social Values, Science and Technology, Eurobarometer 2005; ${ }^{9}$ REMID 2007 og RIRF 2007.

I EU er der med ovenstående udregning i 2007 mellem 13.095.204 og 15.046.048 muslimer, hvilket svarer til 2,8-3,2 pct. af EU's nuværende befolkning. Dette tal stemmer godt overens med de tal, som den amerikanske regering oplyser i Report on International Religious Freedom (2007). Det samme er ikke gældende for hele Europa, hvilket skyldes, at den amerikanske regering ikke baserer deres estimering på en geopolitisk afgrænsning af Europa. Eksempelvis er Georgien inkluderet og Kasakhstan ekskluderet i deres udregning.

Politiske betingede vurderinger, som bl.a. den danske politiker Mogens Camre fremkommer med, stemmer altså ikke overens med de mest anvendelige opgørelser, der findes i dag (se note 4). Nærlæser man Mogens Camres udtalelser over år, vil man også forstå, at tallet han fremkommer med, er en politisk betinget vurdering, som passer bedre med det trusselsbillede, han fremmaner af 'den muslimske trussel' i EU/Europa. ${ }^{18}$ I den kontekst passer trusselsbilledet bedre, jo større den muslimske befolkningsgruppe er jo mere skræmmende, hvorfor denne form for politisk logik nødvendigvis må få 14-16 millioner muslimer til at udgøre 30 millioner (eller flere).

\section{Kvantificeringen af den 'muslimske tilstedeværelse'}

Udfordringen i at kvantificere den 'muslimske tilstedeværelse' eller en hvilken som helst anden religiøs gruppe, relaterer sig ikke kun til de få tilgængelige data, men også til den kendsgerning, at der er mere end en definition på, hvem som skal inkluderes, og hvem der ikke skal. En 'muslimsk tilstedeværelse' og muslimsk identitet i Europa kan måske rimeligvis diskuteres uden eksplicitte definitioner i en række af ikke-statistiske kontekster. Men det står klart, at ethvert forsøg på at tælle en population kræver en præcis bestemmelse af, hvad der konstituerer et medlemskab af en given gruppe. Udover, at være en grundlæggende præmis for statistiske opgørelser, er præcise data også vigtige i en sociopolitisk kontekst. Behovet for religionsstatistiske og -demografiske data efterlyses af mange forskellige uafhængige interessegrupper med modsatrettede perspektiver $\mathrm{i}$ forhold 
til hvad der skal måles. Bl.a. ytrer følgende interessegrupper allerede ønsker for en bedre religionsdemografi i Danmark:

- Religiøse grupper - herunder Folkekirken - er ivrige efter at demonstrere den numeriske størrelse for lige netop deres gruppe. Af hensyn til tiendegrundlag er optælling nødvendig. Kan også gælde andre trossamfund.

- Forskere som ønsker kvantitative vidnesbyrd til at (re)evaluere sekulariseringstesen samt kvalificere forskning indenfor andre relevante områder.

- Centrale myndigheder som søger et mere meningsfyldt grundlag til at klassificere Danmarks etniske og religiøse minoriteter ud fra.

- Lokale myndigheder, sundhedsmyndigheder m.fl. som ud fra pragmatiske forhold ønsker oplysninger i relation til afklaring af servicebehov (eksempelvis tilberedning af mad til børn, ældre og patienter).

Interessegruppens behov og målpopulation kan variere. Eksempelvis vil forskere, der ønsker at (re)evaluere sekulariseringstesen, måske ønske en mere snæver definition på, hvad religiøs identitet er, end dem som er optaget af klassificeringen af etnisk, religiøs og kulturel tilhørsforhold. I betragtning af det religionsdemografiske datavakuum og den meget politiserede antalsdebat, er vigtigheden af eksplicitte definitioner og klart angivne forudsætninger i kvantificering selvindlysende.

Hvis man skal nå frem til en realistisk opgørelse i et land som Danmark, hvor religionsstatiske opgørelser ikke forefindes officielt, eksempelvis i form af folketællinger, kræver det altså en vis kreativitet fra forskerens side. Demografiske analyser og statistikker over antal er nødt til at fremkomme på baggrund af indirekte data.

En måde at opgøre antallet af muslimer (og andre såkaldte migrantreligioner) kan gøres på følgende måde (der tages udgangspunkt i Danmark som eksempel, men det er en metode, som er applicerbar i de fleste lande i Europa, da de fleste officielle statistikker inkluderer et statsborgerskabskriterium):

Der er tre led i beregningerne:

Første led er Danmarks Statistiks oplysninger om, hvor mange indvandrere og efterkommere, voksne som børn, der bor i Danmark, og som kommer fra 73 lande med en større muslimsk befolkning (en muslimsk befolkning på over 3 pct.). Asylansøgere tælles 
ikke med, for de har ikke fået opholdstilladelse. Endvidere tælles EU lande ikke med, da det forudsættes, at nettomigrationen i de fleste EU-lande er ca. $0 .^{19}$

Danmarks Statistik oplyser altså, hvor mange indvandrere og efterkommere fra de 73 nationaliteter, der findes i Danmark. Men ikke, hvor mange af dem der betragter sig selv som muslimer. Da optællingen ønsker at undgå en etnificering af religion er det nødvendigt, at reducere nationalitetstallet på baggrund af andre indirekte tal. Derfor tages der udgangspunkt i den andel af befolkningen i deres oprindelige hjemlande, der er muslimer. Når der eksempelvis er 98 pct. af indbyggerne i Marokko, der ifølge de mest pålidelige undersøgelser er muslimer, antages det, at også 98 pct. af marokkanerne i Danmark er muslimer. Det er selvfølgelig en problematisk antagelse især hvad angår flygtningegrupper, idet de netop kan være flygtet på baggrund af religiøs forfølgelse, som derfor kan skævvride dette tal. Den halvårlige undersøgelse IntegrationsStatus fra Catinet Research (Mikkelsen 2003; 2004) giver relativt pålidelige data i forhold til de syv største etniske gruppers religiøse tilhørsforhold. Disse syv etniske grupper svarer til ca. $75-80$ pct. af den samlede population der undersøges. Disse tal baseret på surveyundersøgelser er de mest præcise vi har at basere opgørelser på baggrund af. I alt giver denne gruppe et tal på 200.747 muslimer ud af de 207.186 i 2006.

Anden del af regnestykket handler om de personer, der har været så længe i Danmark, at de ikke længere er registreret under kategorierne indvandrere eller efterkommere i Danmarks Statistik. Det er typisk tredjegeneration i en indvandrerfamilie, der er tale om her. De er født i Danmark af forældre, hvoraf mindst den ene er dansk statsborger. For at få tredjegeneration med i en opgørelse af muslimer, kan man med udgangspunkt i de fire ældste indvandrergrupper i Danmark, dvs. tyrkerne, pakistanerne, marokkanerne og eksjugoslaverne, foretage en beregning af, hvor mange danske tredjegenerationsmuslimer, der kan skønnes at være. De fire nationaliteter er valgt, fordi de stort set er de eneste, der har været i landet så længe, at der er kommet en tredje generation hos dem her i landet. Det er svært at opstille forudsætninger for de fire nationaliteter, hvad angår fødsler, men fertilitetsundersøgelser viser, at andengenerationskvinder fra tredjeverdens lande hastigt er ved at nå samme (lave) fødselsrate som den gennemsnitlige danske kvinde. Derfor er det rimeligt at antage, at tredjegenerationskvinders fødselsrate ligner den gennemsnitlige danske kvindes fødselsrate (Jacobsen 2007: 153-155). I denne antagelse forudsættes det, 
at kvinderne i alderen 15-19 ingen børn har, 20-29 har et barn og 30- har to børn. Således når antallet af muslimer fra denne tredje generation op på 4.133 efter reduktion. Lægges denne gruppe til den første store gruppe på 200.747, giver det et mellemfacit på 204.880 muslimer i Danmark.

Tredje del af regnestykket omfatter gruppen af danskere, der har konverteret til islam. Dette tal baserer sig på religionsforskerne Tina G. Jensen og Kate Østergaards og undersøgelse af konversion til islam i Danmark. Deres samlede skøn lyder på et sted mellem 2.100 og 2.800 danske konvertitter (Jensen og Østergaard 2007: 181). I denne opgørelse er det laveste tal valgt af forsigtighedsmæssige årsager. Dermed kommer det samlede antal for muslimer i Danmark pr. 1. februar 2006 op på tallet 207.186. Det svarer til 3,8 pct. af den danske befolkning (Jacobsen 2007). ${ }^{20}$

Afslutningsvis er det rimeligt at pege på visse forbehold overfor beregningsmetoden. For det første er skønnet over, hvor mange efterkommere af efterkommere (dvs. tredjegenerationsindvandrere), der er muslimer baseret på en lang række antagelser, som ikke er nærmere undersøgt. Vi kender eksempelvis ikke den præcise fertilitetskvotient for disse indvandrergrupper. For det andet er der aldrig tegnet nogen præcis social og kulturel profil af de indvandrede arbejdsimmigranter og flygtninge, som kunne give viden om indvandrernes eventuelle religion. For det tredje er det procentvise antal muslimer per etniske gruppe en statisk antagelse, som i realiteten ændrer sig over tid, hvilket der ikke er taget højde for i undersøgelsen. Det vil sige, at antallet af muslimer kan stige i en etnisk gruppe i en periode, mens det kan falde i en anden (ibid.).

\section{En tentativ prognose for udviklingen af muslimer i Danmark}

En befolkningsprognose for udviklingen i antallet af muslimer i Danmark kan kun være teoretisk, så længe datamaterialet er indirekte. Omvendt er befolkningsprognoser, som tidligere omtalt, generelt en usikker disciplin på grund af antagelser om fremtidige fertilitetskvotienter, migration og dødsfald - forhold som ofte ændrer sig på grund af uforudsete sundheds- og samfundsmæssige samt kulturelle udviklinger. Hvis man alligevel vil forsøge at udarbejde en prognose for antallet af muslimer i Danmark - en tentativ prognose - så kan man anvende samme fremskrivninger, som Danmarks Statistik kommer frem 
til i udregningen af antallet af indvandrere og efterkommere fra ikke-vestlige lande fra 2005 til 2050 (Arbog om udlcendinge i Danmark 2005: 58-9). Denne statistiske kategori benyttes, da det er i denne gruppe, at langt de fleste muslimer er, og der er ingen grund til at antage, at deres demografiske profil ser meget anderledes ud end gruppens gennemsnitlige.

Indvandrere og efterkommere fra ikke-vestlige lande vil ifølge Danmarks Statistik vokse med 92,3 pct. fra 2005 til 2050. Benytter man samme relative forskel til at udregne befolkningsudviklingen for muslimer i Danmark fra 2005 til 2050, vil antallet af muslimer vokse fra 204.388 i 2005 til 393.038 i 2050 (dette tal er inklusiv en beregning af tredjegenerationsindvandrere og konvertitter, jf. Jacobsen 2007: 159). Dvs. fra 3,8 pct. af den danske befolkning i 2005 til 7,1 pct. af befolkningen i 2050 .

Følgende antagelser om fertilitet, indvandring og udvandring gælder for Danmarks Statistiks prognose (Arbog om udlcendinge i Danmark 2005: 58): For gruppen af indvandrere fra ikke-vestlige lande forventes en aftagende fertilitet fra 2,3 i 2005 til 2,1 i 2030. Derefter forventes konstant fertilitet. Den årlige indvandring af personer fra ikke-vestlige lande forudsættes at stige støt fra 11.000 personer i 2005 til 14.000 personer i 2030, hvorefter raten vil ligge konstant. Den årlige indvandring af efterkommere fra ikke-vestlige lande forudsættes at stige fra 900 i 2005 til 2.000 i 2030. Det sidstnævnte niveau holdes konstant frem til 2050. For udvandringshyppigheden forudsættes en jævn stigning frem til 2030 på 0,75 pct. for indvandrergrupperne og 0,5 pct. for øvrige grupper. Efter 2030 regnes med konstante hyppigheder (ibid.: 58-9). Denne prognose forudsætter, at der ikke sker dramatiske ændringer i antallet af konversioner til islam i Danmark eller apostasi (frafald). Andre spørgsmål der kan ændre dette tal, er faldende fertilitet i den nævnte gruppe, migration eller immigration. Især spørgsmålene om faldende fertilitet og immigration er aktuelle, dels fordi fertiliteten på europæisk plan netop viste sig at være lavere blandt muslimske kvinder (1,6 modsat 2,3 for gruppen af kvindelige indvandrere og efterkommere fra ikke-vestlige lande (Westoff og Frejka 2007: 796-98)), dels fordi den vestlige verden på grund af den demografiske udvikling, hvor ældre udenfor arbejdsstyrken kommer til at fylde relativt mere i den generelle befolkning, vil kræve indvandring af arbejdskraft, hvis den nuværende produktivt skal bevares og/eller udbygges (Matthiessen 2004: 89-95). 


\section{Konklusion}

Det er vigtigt at understrege, at præciseringen af estimeringen af muslimer i Europa generelt og i de enkelte europæiske lande er vigtig af flere årsager; 1 . det er vigtigt for forskere, der beskæftiger sig med sociopolitiske forhold i relation til de muslimske befolkningsgrupper, 2. politikere og myndigheder der skal træffe beslutninger der berører disse grupper på den ene eller anden måde, er nødt til at kende et mere præcist antal og, hvis andet ikke er muligt, tentative demografiske prognoser over gruppens udvikling, 3. det kan være med til at afpolitisere talspørgsmålet og udrydde fordomme i offentligheden om de muslimske befolkningsgruppers størrelse og vækstpotentiale.

I den sammenhæng er det vigtigt at forskere, der beskæftiger sig med de berørte grupper, ikke underkender betydningen af tallenes vigtighed. Samtidig reflekterer de udbredte forestillinger om antal og vækst en generel mangel på præcisering og konsensus i forskningsmiljøer, der beskæftiger sig med islam og muslimer i Europa. Validiteten af den religionsdemografiske forskning der vedrører spørgsmålet om antal og vækst i den berørte gruppe, er derfor uomgængelig.

I denne artikel præsenteredes en metode til en mere præcis udregning af antallet af muslimer, som tager hensyn til individets identitetsmæssige valg i det omfang, det er muligt. Den benytter sig af surveys foretaget blandt udvalgte etniske grupper, som svarer på spørgsmålet om religiøs identitet. Hvor surveys ikke er tilgængelige, benyttes i metoden andre undersøgelser fra den etniske gruppes hjemland, som angår spørgsmålet om religiøs identitet. På denne måde undgår man etnificeringen af religion, som har været en udbredt metode til at estimere antal af muslimer - et tal der af samme grund derfor er blevet større end hvad rimeligt er.

Uanset resultatet af disse forhold, er der ingen demografiske undersøgelser af muslimer i Europa, som tyder på, at islamforskningens 'grand old man', Bernard Lewis får ret i sin forudsigelse om, at Europa mod slutningen af det 21. århundrede vil være totalt islamiseret?

\section{Litteratur}

BBC 2005: http://news.bbc.co.uk/2/hi/europe/4385768.stm 
Barrett, David B. (ed.) 1982: World Christian Encyclopedia. A comparative study of churches and religions in the modern world AD 1900-2000. Nairobi: Oxford University Press.

Barrett, David. B., George T. Kurian og Todd M. Johnson (ed.) 2001: World Christian Encyclopedia. A comparative survey of churches and religions in the modern world, bd. 1. Oxford: Oxford University Press.

Baumann, Gerd 1996: Contesting culture. Discourses of identity in multi-ethnic London. Cambridge, Cambridge University Press.

Britannica Book of the Year 1994-2006: Chicago: Encyclopædia Britannica.

Brown, Mark 2000: "Quantifying the Muslim population in Europe: conceptual and data issues", i International Journal of Social Research Methodology, vol. 3, No. 2, pp. 87-101.

Burleigh, Michael 2005: Earthly powers. Religion and politics in Europe from the enlightenment to the Great War. London, HarperCollins.

Census of Population, Households and Dwellings 2003: Republic of Montenegro, Statistical Office. http://www.monstat.cg.yu/Popis/Popis01a.zip.

CIA. The World Factbook 2007: www.cia.gov/library/publications/the-world-factbook, CIA, US Government.

Coleman og Salt 1996: "The ethnic group question in the 1991 Census: a new landmark in British social statistics", i D. Coleman and J. Salt (eds) Ethnicity in the 1991 Census, vol. 1 (London: HMSO) pp. 1-33.

Danmarks Statistik 2007: www.dst.dk, Danmarks Statistik

Dassetto, Felice; Silvio Ferrari og Brigitte Maréchal 2007: Islam in the European Union: What's at stake in the Future? European Parliament's committee on Culture and Education. Policy Department Structural and Cohesion Policies, European Parlament.

European Monitoring Centre on Racism and Xenophobia 2006: Muslims in the European Union, Discrimination and Islamophobia, http://fra.europa.eu/fra/material/pub/muslim/Manifestations_EN.pdf, EUMC

Feldbæk, Ole og Ole Justesen 1980: Kolonierne i Asien og Afrika. Kbh.: Politiken. 
Financial Times 2003: Muslims in Europe. http://news.ft.com/cms/caa4d7f2-f491-11d99dd1-00000e2511c8.swf

Inglehart, Ronald et al. 2004: Human Beliefs and Values. A cross-cultural sourcebook based on the 1999-2002 values surveys. México: Siglo veintiuno Editors.

Jacobsen, Brian 2007: ”Muslimer i Danmark - en kritisk vurdering af antalsopgørelser”, i Margit Warburg og Brian Jacobsen (eds.) Tørre tal om troen. Religionsdemografi $i$ det 21. århundrede. Højbjerg, Univers, pp. 143-165.

- 2006: 'Religionernes genkomst på den politiske dagsorden.' i Tidsskriftet Politik Nummer 1, Årgang 9, s. 26-37.

Jenkins, Philip 2006: "Demographics, Religion, and the Future of Europe" i Orbis. A Journal of World Affairs 50, nr. 3, pp. 519-539.

Jensen, Tina G. og Kate Østergaard 2007: ”Omvendelse til islam i Danmark - gætterier og realiteter", i Margit Warburg og Brian Jacobsen (eds.) Tørre tal om troen. Religionsdemografi i det 21. århundrede. Højbjerg, Univers, pp. 166-184.

Keysar, Ariela, Barry A. Kosmin and Egon Mayer 2001: American Religious Identification Survey 2001. The Graduate Center of the City University of New York, www.gc.cuny.edu/faculty/research_briefs/aris.pdf.

Kirkeministeriet 2007: www.km.dk/26.html.

Laurence, Jonathan og Justin Vaisse 2006: Integrating Islam. Political and religious challenges in contemporary France. Washington, D.C.: Brookings Institution Press.

Lüchau, Peter 2005: 'Danskernes gudstro siden 1940'erne”, i Morten Thomsen Højsaard og Hans Raun Iversen (eds.) Gudstro i Danmark. København, Anis, pp. 31-58.

Matthiessen, Poul Chr. 2004: Befolkning og samfund. København, Handelshøjskolens Forlag.

Maréchal B. (Coord.) 2002: A Guidebook on Islam and Muslims in the Wide Contemporary Europe. Louvain-la-Neuve: Academia Bruylant.

Maréchal B. et al. 2003: Muslims in the enlarged Europe. Religion and Society. Leiden: Brill.

Melton, Gordon og Baumann, Martin 2002: Religions of the World - a comprehensive encyclopedia of beliefs and practices, Vol. I-IV. Santa Barbara, Calif. ABC-CLIO. 
Mikkelsen, Flemming og Research Catinét 2003: IntegrationsStatus 1999-2003. København, Catinét Research.

- 2004: IntegrationsStatus 1. halvår 2004. København, Catinét Research.

Nielsen, Jørgen 1995: Muslims in Western Europe. $2^{\text {nd }}$ ed. Edinburgh: Edinburgh University Press.

Park, Alison et al. 2007: British social attitudes, the 23rd report. Perspectives on a changing society. London, Sage.

Peach, Ceri og Günther Glebe 1995: "Muslim minorities in western Europe", Ethnic \& Racial Studies, Vol. 18 Issue 1, pp. 26-45.

Remid 2007: Religionswissenschaftlicher Medien- und Informationsdienst e. $V$. www.remid.de.

Report on International Religious Freedom 2007: US Department of State's Annual Report on Religious Freedom. http://www.state.gov/g/drl/rls/irf/.

Report on International Religious Freedom 2004: US Department of State's Annual Report on Religious Freedom http://www.state.gov/g/drl/rls/irf/2004/35454.htm.

Rigsdagstidende 1850-1953, J.H. Schultz Universitets-bogtrykkeri.

Roesen, August 1976, Dansk kirkeret. Kbh.: Den Danske Præsteforening.

Rowland, Donald T. 2003: Demographic methods and concepts. Oxford, Oxford University Press.

Roy, Oliver 2003: "EuroIslam: The Jihad Within?”, i National Interest.

- 2004: Globalized Islam. The Search for a New Ummah, New York, Columbia University Press.

Said, Edward 2002: Orientalisme. Vestlige forestillinger om Orienten. Roskilde, Roskilde Universitetsforlag.

Salvatore, Armando 1997: Islam and the Political Discourse of Modernity. Reading, Ithaca Press.

Social Values, Science and Technology, Eurobarometer 2005: European Commission. http://ec.europa.eu/public_opinion/archives/ebs/ebs_225_report_en.pdf.

Stenberg, Leif 2002: "Islam in Scandinavia", i Shireen T. Hunter (ed.), Islam, Europe's second religion. The new social, cultural, and political landscape. Westport, Conn., Praeger pp. 121-140.

(C) Forfatteren og Tidsskrift for Islamforskning, ISSN 1901-9580, publiceret 18-02-2008 
Vertovec, Steven og Ceri Peach (ed.) 1997: Islam in Europe. The Politics of Religion and Community. London: Macmillan Press.

Warburg, Margit 2007a: "Hvorfor religionsdemografi?", i Margit Warburg og Brian Jacobsen (eds.) Tørre tal om troen. Religionsdemografi i det 21. århundrede. Højbjerg, Univers, pp. 5-13.

- 2007b: "Metodiske problemstillinger i religionsdemografien", i Margit Warburg og Brian Jacobsen (eds.) Tørre tal om troen. Religionsdemografi i det 21. århundrede. Højbjerg, Univers, pp. 16-37.

Warburg, Margit og Brian Jacobsen (eds.) 2007: Tørre tal om troen. Religionsdemografi i det 21. århundrede. Højbjerg, Univers.

Westoff, Charles F.og Tomas Frejka 2007:'Religiousness and Fertility among European Muslim", i Population and Development Review, Vol. 33, Number 4, Blackwell Publishing, pp. 785-809(25).

Wilks, I. 2008, “Ghana.” Encyclopaedia of Islam. Edited by: P. Bearman, Th. Bianquis , C.E. Bosworth , E. van Donzel and W.P. Heinrichs. Brill, 2008. Brill Online. DET KONGELIGE BIBLIOTEK Copenhagen. 02 January 2008

Zahle, Henrik 2003, Menneskerettigheder. Dansk forfatningsret 3. København: Christian Ejlers' Forlag.

Arbog om udloendinge i Danmark 2004, København: Ministeriet for Flygtninge, Indvandrere og Integration.

Arbog om udlaendinge i Danmark 2005: København: Ministeriet for Flygtninge, Indvandrere og Integration.

Brian Arly Jacobsen er religionssociolog og ph.d.-stipendiat på Afdeling for Religionshistorie, Institut for Tværkulturelle og regionale studier, Københavns Universitet.

\footnotetext{
${ }^{1}$ Denne artikel er omarbejdet efter foredrag afholdt på et seminar i Forum for Islamforskning den 12. oktober 2006, Københavns Universitet. Tak for venlig kritik af engagerede deltagere.

${ }^{2}$ Danskere mødte også muslimer (samt kristne, hinduer m.fl.) i de danske kolonier i Trankebar (som senere blev solgt til Storbritannien i 1845 (Feldbæk og Justesen 1980: 89-95)) og i de forskellige handelsstationer på Guldkysten (nuværende Ghana) såsom Fort Christiansborg, Fort Frederiksborg og Frederiksberg (som senere blev solgt til Storbritannien i 1850 (Wilks 2008; Feldbæk og Justesen 1980: 289-299)). Om der kom muslimer til Danmark gennem disse kolonier er ikke undersøgt, men det kunne være en interessant opgave i sig selv.

${ }^{3}$ Se eksempelvis Roy $(2003 ; 2004)$ for en diskussion af nye former for islam i Europa.
} 


\footnotetext{
${ }^{4}$ Se eksempelvis følgende medier og institutioners opgørelser over muslimer i Europa: BBC (2005); Financial Times (2003); Reformatorisch Dagblad: "Europa telt ruim 53 mln. Moslims" 4.5.2007; European Monitoring Centre on Racism and Xenophobia (2006); Muslims in the European Union, Discrimination and Islamophobia og Report on International Religious Freedom (2007). Politikere fremkommer også med talvurderinger fra tid til anden. Mogens Camre (Dansk Folkeparti) vurderede eksempelvis 20.10.2006 I Nyhedsavisen, at der var 30 millioner muslimer i EU.

${ }^{5}$ Det skal dog understreges, at der også findes religionsstatistik opstillet ud fra videnskabelige metoder med strengt videnskabelige formål, se f.eks. Inglehart et al. (2004); Keysar et al. (2001); Park et al. (2007) og Warburg og Jacobsen (2007).

${ }^{6}$ Se eksempelvis formanden for Dansk Folkepartis Ungdomsorganisation, Kenneth Kristensen i Berlingske Tidende, 26.2.2000: "Vores velfærdssamfund er opbygget af flere generationer, men vi ser en regulær invasion af muslimer" eller pressemeddelelse af folketingskandidat for Det konservative Folkeparti Rasmus Jarlov 24.7.2007; indlæg i Berlingske Tidende, 7.2.2006 af formanden for Dansk Forum, Adam Wagner; Jyllands-Postens leder 18.2.2006 samt et utal af læserbreve i aviserne af mere eller mindre kendte danskere.

${ }^{7}$ Skilsmisseregistrering gælder ikke for Danmark jf. Roesen (1976: 99-107; 348-53) og Zahle (2003:15569).

${ }^{8}$ Jf. debat i Rigsdagen ang. dette emne i november/december 1935 (Rigsdagstidende 1935/36: 779-80; 1088).

${ }^{9}$ Registertilsynet er oprettet efter vedtagelsen af lov nr. 293 af 8. juni 1978 om private registre og lov nr. 294 af 8. juni 1978 om offentlige myndigheders registre. Baggrunden herfor var Registerudvalgets betænkning nr. 687 af 1973 om private registre og Registerudvalgets betænkning nr. 767 af 1976 om offentlige myndigheders registre.

${ }^{10}$ EU's medlemslande og udvidelser (årstal i parentes) i den undersøgte periode: Tyskland, Frankrig, Italien, Belgien, Holland, Luxembourg, Danmark, Irland, Storbritannien, Grækenland, Spanien og Portugal. Østrig, Finland og Sverige (1995). Tjekkiet, Estland, Cypern, Letland, Litauen, Ungarn, Malta, Polen, Slovenien og Slovakiet (2004). Bulgarien og Rumænien (2007).

${ }^{11}$ For en diskussion af problemerne med World Christian Encyclopedia's udregninger se Warburg (2007b: 18-19).

${ }^{12}$ Svarende til 2,08 pct. af EU's befolkning i 1995.

${ }^{13}$ Svarende til 3,68 pct. af EU's befolkning i 2007.

${ }^{14}$ I den demografiske forskningsdisciplin benytter man præcise tal ned til sidste ciffer i udregninger af befolkningsgruppers nuværende størrelse og prognoser over udviklingen af samme (Matthiessen 2004). Samme tilgang benyttes i denne artikel, når det gælder udregninger af de muslimske befolkningsgruppers størrelse og prognoser over denne.

${ }^{15}$ Det skal understreges, at de officielle statistikkers oplysninger ikke nødvendigvis er troværdige. De kan, som det var tilfældet med Danmarks Statistiks oplysninger om muslimer i Statistisk Årbog i 1990'erne, være et resultat af en enkelt forskers vurdering af antallet af eksempelvis muslimer på baggrund af fødselsoprindelse og statsborgerskab.

${ }^{16}$ Disse spørgsmål bygger på Warburg (2007:6).

${ }^{17}$ Coleman and Salt's tabel er ikke helt korrekt idet Norge ikke har en officiel religionsstatistik, men blot registrer skattebetalere for forskellige trossamfund gennem staten, Portugal spørger om alle fire variable $\mathrm{i}$ deres folketællinger og Østrig spurgte først om etnisk tilhørsforhold og fødselsoprindelse i deres folketælling fra 2001. I tidligere folketællinger spurgte de ikke om fødselsoprindelse, som Coleman og Salt anfører i deres tabel (jf. de enkelte landes nationale statistiske bureauers hjemmesider).

${ }^{18}$ Eksempelvis skrev Camre i 2001 i sit talemanuskript omdelt til pressen under Dansk Folkepartis årsmøde 16. september at "Alle Vestens lande er infiltreret af muslimerne - nogle af dem taler pænt til os, mens de venter på at blive nok til at slå os ihjel." ("slå os ihjel" blev på talerstolen ændret til "få os fjernet").

${ }^{19}$ Nettomigration = immigration - emigration (Warburg 2007: 27).

${ }^{20}$ For en mere grundig gennemgang af metoden og resultaterne af dette se Jacobsen (2007).
} 